\title{
Bionomics and Taxonomy of Leafhopper Sophonia orientalis (Homoptera: Cicadellidae), a Pacific Pest Species in the Macaronesian Archipelagos
}

\author{
D. AGUIN-POMBO, ${ }^{1,2}$ A. M. FRANQUinho AGUIAR, ${ }^{3}$ and V. G. KUZNETSOVA ${ }^{4}$
}

\begin{abstract}
Ann. Entomol. Soc. Am. 100(1): 19-26 (2007)
ABSTRACT The leafhopper Sophonia orientalis (Matsumura) (Homoptera: Cicadellidae) is native to Asia, but it has been recently introduced to the Hawaii Archipelago, CA and French Polynesia. Although this extremely polyphagous species is considered to be a threat to all native plants of Hawaii and to many economically important cropping cultures, its taxonomy remains obscure. Most literature referred to this species as Sophonia rufofascia (Kuoh \& Kuoh), but recently it has been shown that previous records of this species correspond to S. orientalis. In this study, S. orientalis is recorded from northeastern Atlantic archipelagos of Madeira and Canaries, with the first collection made in 2000 representing the first record of this species for Macaronesia. Diagnosis of the species together with information on the karyotype and structure of testes and ovaries is given. The number of chromosomes is $2 \mathrm{n}=16+\mathrm{X} 0$ (males) and $2 \mathrm{n}=16+\mathrm{XX}$ (females), and each testis and ovary is composed of six follicles and six ovarioles, respectively. In Madeira, S. orientalis was found on 28 plant species, including native and endemic plants, but it also was associated with important crops such as vineyards. The presence of adults and nymphs during most of the year suggests that this species has several annual generations. Owing to the suitable climate and the presence of a great number of host plants, its potential for detrimental effects to Madeira ecosystems is considered to be great, and the proximity of Madeira and Canary Islands to the European land mass suggests that this pest may spread.
\end{abstract}

KEY WORDS Sophonia orientalis, Madeira, Canary Islands, leafhoppers, exotic species

Sophonia orientalis (Matsumura) (Homoptera: Cicadellidae) is a serious pest species of many economically important plants in the Hawaiian archipelago. It was originally described from Taiwan (Kuoh and Kuoh 1983), but it seems to be native to nearby regions of China, Pakistan, and Japan ( $\mathrm{Li}$ and Chen 2005). In 1987, it was found also in the Hawaii Islands, probably having been introduced from southeastern Asia (Heu and Kumashiro 1989), and since its introduction to Hawaii it has been extending successfully over all major islands of this archipelago (Howarth et al. 2001). In 1996, it reached California and recently has been reported also from French Polynesia, including the Marquesas, Society, and Australs islands (Polhemus 2001, Englund 2004). Presently, this leafhopper imposes a quarantine action to other regions such as Australia.

S. orientalis is highly polyphagous, being associated with >300 plant species from 83 plant families

\footnotetext{
${ }^{1}$ Centre for Macaronesian Studies, University of Madeira, Campus da Penteada, 9000-390 Funchal, Madeira, Portugal.

2 Corresponding author, e-mail: aguin@uma.pt.

${ }^{3}$ Regional Secretary for the Environment and Natural ResourcesAgricultural Quality Laboratory, Caminho Municipal dos Caboucos 61, 9135-372 Camacha, Madeira, Portugal.

${ }^{4}$ Department of Karyosystematics, Zoological Institute, Russian Academy of Sciences, 199034 St. Petersburg, Russia.
}

(Fukada 1996). It is considered as a major agricultural pest, which damages several crops growing in Hawaii, such as coffee, banana, taro, guava, mango, and macadamia nuts (Howarth et al. 2001). Additionally, its food plants include 15 rare or endangered native endemic plant species of Hawaii. It is a major threat to some of these endemics, such as Dicranopteris linearis ferns (Follett et al. 2003), Cyanea glabra (USFWS 1997) or Hibiscadelphus giffardianus rock trees (USFWS 1995, 1996, 2002). However, this leafhopper also causes indirect damage to endemic or native animal species that use native plants. For example, in Hawaii the heavy damage to $D$. linearis ferns caused by this leafhopper is considered as a threat to the endemic bird Puffinus newelii Henshaw, 1900, which nests in burrows protected by these plants (Birdlife 2004). Nowadays, this extremely polyphagous species is considered to be a potential threat to all native taxa of Hawaii (USFWS 1997). The damage to plants caused by this leafhopper can result in the death of affected leaves and the whole plant, owing to the combined action of its feeding and oviposition behavior. The main feeding effects are chlorosis, vein browning, and shorter stem length, also known as hopperburn (Backus et al. 2005), whereas damage to vascular bundles is caused by oviposition into midveins (Jones et al. 2000). Although the damage pro- 
duced by this leafhopper to papaya was similar to the symptoms produced by phytopathogens, it has been demonstrated that $S$. orientalis is not a vector of virus yellows (Jones et al. 1998).

When dealing with new infestations, there is a need for information to assist with early detection and accurate identification; however, the taxonomic status of S. orientalis is unclear. The main difficulties are basically owing to synonymy errors, poor descriptions, and unclear delimitation between this and closely related genera. Thus, although all recent literature on the economic damage of S. orientalis refers to this species as Sophonia rufofascia (Kuoh and Kuoh 1983), Webb and Viraktamath (2004) after studying material from the United States (Hawaii and California), China, Taiwan, and Madeira concluded that all belong to the species S. orientalis (Matsumura 1912). However, this identification is provisional and is still pending the study of the type material from these two speciesPseudonirvana rufofascia Kuoh and Kuoh, 1983 and Nirvana orientalis Matsumura, 1912-which were not available to Webb and Viraktamath. In addition to the nomenclature problems, there is not a clear and complete description of this invasive species available; instead, there are inadequate descriptions found scattered in different taxonomic works under different species names with poor diagnostic characteristics. In contrast to taxonomic work, much research has been done on the biology, host plant associations, feeding damage, and egg parasitoids of populations in Hawaii (Jones et al. 1998, 2000; Duan and Messing 2000; Yang et al. 2000; Lenz and Taylor 2001; Alyokhin et al. 2001, 2004). Yet, almost nothing is known on the biology of this species in its area of origin, and the results obtained from Hawaii do not necessarily apply to populations from other regions. The chance of invasion in a new region will depend not only on its climatic and ecological conditions but also on the biological, ecological, and genetic characteristics of invader populations (Sakai et al. 2001). Thus, detailed information should be gathered after each new invasion to analyze the risk of a new pest.

In this work, the presence of S. orientalis is reported from the Macaronesian archipelagos together with data on host plant associations, phenology, and distribution. The specimens from Madeira that were studied previously by Webb and Viraktamath (2004) were from our samples. A morphological description with illustrations of genital structures based on material from Madeira is provided and the number of chromosomes, which is often useful for the identification of leafhopper species complexes, is determined. In addition, the structure of testes and ovaries with reference to the number of testicular follicles and ovarioles is reported. Finally, the potential of this species for detrimental effects to Macaronesian ecosystems is discussed.

\section{Materials and Methods}

Morphological Studies. The material studied was sampled by several collectors. The collectors' initials are as follows: CB, C. Brazão; DAP, D. Aguin-Pombo;
EF, E. Freitas; EN, E. Nunes; FA, F. Aguiar; FR, F. Reis; JJ, J. Jesus; MG, M. Gouveia; NF, N. Freitas; OC, O. Costa; and SF, S. Filipe. Voucher specimens have been deposited in the Museum, Municipal de Funchal (Madeira), the Agricultural Quality Laboratory collection of Camacha (Madeira), the Entomological collection of the University of Madeira, the Paris National Museum of Natural History, the Bishop Museum, the Musée de la Nature et de l'Homme de Ténériffe, and the personal collection of the first author.

Karyological Studies. Young males and male nymphs were collected in a garden on the ornamental plant Acalypha wilkesiana Muell.-Arg. The specimens were fixed immediately after capture in a 1:3 mixture of acetic acid and ethanol. The testes were removed from the abdomen, placed in a drop of $45 \%$ acetic acid, covered by a coverslip, and squashed. Some specimens were taken alive. From these live specimens, testicular follicles were removed on a microscope slide in a drop of hypotonic $(0.97 \%)$ sodium citrate solution for $\approx 5$ min and then transferred to a drop of $45 \%$ acetic acid. The slides were preliminarily examined using phase-contrast microscopy. From the best preparations the coverslips were removed by a dry ice technique (Conger and Fairchild 1953). Then, the slides were dehydrated in fresh fixative for $30 \mathrm{~min}$, air-dried, and stained according to the Feulgen-Giemsa protocol as described by Grozeva and Nokkala (1996) with minor modifications. The slides were treated in $1 \mathrm{~N}$ $\mathrm{HCl}$ at room temperature for $20 \mathrm{~min}$; hydrolyzed in 1 $\mathrm{N} \mathrm{HCl}$ at $60^{\circ} \mathrm{C}$ for $7 \mathrm{~min}$; stained with Schiff's reagent for $30 \mathrm{~min}$; rinsed with distilled water; immersed in Sorensen's phosphate buffer, $\mathrm{pH}$ 6.8, for $5 \mathrm{~min}$; and stained with 5\% Giemsa in Sorensen's buffer for 30 min. After staining, the preparations were rinsed with distilled water, air-dried, and mounted in Entellan.

Ecological Studies. Some of the specimens studied were sampled by sweeping with a net on plant foliage. Plants were identified by the authors and the collectors according to Press and Short (1994). Data on the seasonal variation was obtained using two water pan traps (Moericke 1955). This type of trap consisted of a round metallic container $35 \mathrm{~cm}$ in diameter and 15 in depth, yellow-colored inside and green outside. These color traps were filled with a solution of water and $2 \%$ of detergent (Teepol), and leafhoppers were collected once per week from 28 June 2000 until 5 December 2001. This study was done in the Tropical and Subtropical Fruits Experimental Station of Madeira. Here, water pan traps were placed within a culture of papaya close to another of avocado; one trap was located inside a greenhouse with papaya and another trap outside within a papaya plantation.

\section{Results}

Sophonia orientalis (Matsumura 1912)

(Adults; Figs. 1-9)

Nirvana orientalis Matsumura 1912: 282. Huang, 1994: 85. Pseudonirvana orientalis (Matsumura 1912). Kuoh 1966: 70. 


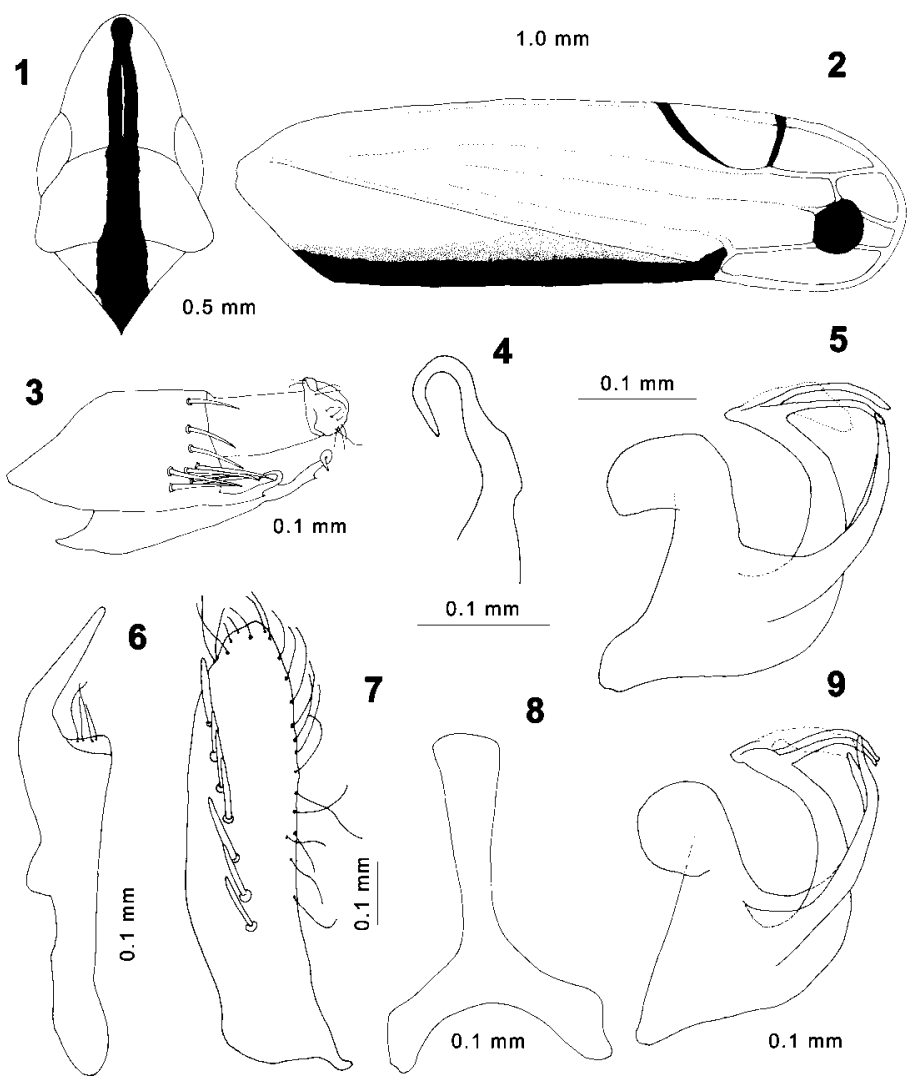

Figs. 1-9. Adult of S. orientalis. (1) Head, dorsal view. (2) Right forewing. (3) Pygofer, lateral view. (4) Pygofer appendix. $(5,9)$ Aedeagus, lateral view. (6) Right style. (7) Right genital plate. (8) Connective.

Pseudonirvana rufofascia Kuoh and Kuoh 1983: 316. Synonymized by Huang, 1994: 85.

Sophonia rufofascia (Kuoh and Kuoh 1983). Huang 1989: 64. Synonymized by Huang 1994: 85.

Quercinirvana longicephala Ahmed and Mahmood 1970: 260. Synonymized in error by Huang 1994: 85. Sophonia orientalis (Matsumura 1912). Transferred by Li and Chen 1999: 51. Webb and Viraktamath 2004: 2,4 .

Description. Length 4.20-5.50 mm. Body depressed with head strongly produced and nearly as broad as pronotum. Overall color yellow with black spot near crown apex continuous with a pair of black longitudinal lines fused at posterior crown margin, continuing as single line to near scutellum apex and extended onto commissural margin of forewing; black lines often bordered laterally with bright red (Fig. 1); forewing with two brown false veins extended to costal margin and black false eyespot at base of median apical cell (Fig. 2); abdominal apex sometimes reddish. Male pygofer with posteroventral appendage slender, strongly recurved apically with preapical tooth on mesal margin (Figs. 3 and 4); aedeagus with a pair of elongate processes arising laterally near base of shaft and curved posterodorsal; pair of slender lateral apical processes extended posteroventral to or near apices of basal processes (Figs. 5 and 9); genital plates parallel sided more than 4 times as long as their width (Fig. 7); connective Y-shaped (Fig. 8); styles with a long oblique apical finger-like process (Fig. 6). Female sternite VII rectangular with posterior margin straight. Nymph with head strongly produced, yellow overall with a pair of black lateral spots on abdominal segment IX.

Intraspecific Variation. Aedeagus variation was observed in the curvature and length of the basal processes, in the curvature of the apical processes and in the extension of red coloration in fore wings.

Measurements. Males: vertex length $0.76 \pm 0.02 \mathrm{~mm}$ (0.71-0.80); pronotum width $0.92 \pm 0.03(0.87-0.98)$; body length $4.37 \pm 0.15(4.2-4.90)$. Females: vertex length $0.99 \pm 0.02 \mathrm{~mm}(0.96-1.01)$; pronotum width $1.06 \pm 0.03 \mathrm{~mm}(1.00-1.10)$; body length $5.17 \pm 0.15$ $\mathrm{mm}$ (4.95-5.50); ([MALE] [MALE] $n=20$ and [FEMALE] [FEMALE] $n=13$ ).

Material Examined. PORTUGAL: Madeira Island: Funchal: 222 males, 77 females, Quebradas, 28-VI2000/27-XII-2001, 120 m, on Moericke traps (FA); 1 male, idem, 13-VI-2002, on light trap (MG); 1 male, Funchal city, 21-IX-2000 (FA); 1 male, 3 females, 14 nymphs, idem, 28-IX-2000 (FA); 2 nymphs, idem, 5-II-2001, $25 \mathrm{~m}$ (NF); 2 females, 4 nymphs, Lido, 27-I-2001, $10 \mathrm{~m}$ (NF); 1 female, idem, 24-III-2001 (NF); 1 female, idem, 26-VI-2001 (NF); 2 nymphs, 


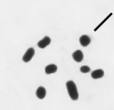

10

11

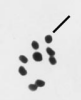

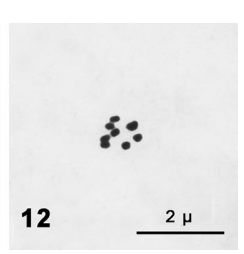

Figs. 10-12. Meiotic chromosomes of males of S. orientalis. (10) Metaphase I. $(11,12)$ Metaphase II. (Bar indicates sex chromosome.)

idem, 7-VII-2001 (NF); 1 female, idem, 26-V-2001 (NF); 1 female, Parque de Santa Catarina, 5-II-2001, $30 \mathrm{~m}$ (NF); 1 female, idem, 27-VII-2001, $30 \mathrm{~m}$ (NF); 3 nymphs, idem, 5-IX-2001 (NF); 1 female, Monte, 7-VII-2001, 500 m (NF); 1 female, Lombo da Boa Vista, 31-III-2001, 175 m (FA); 1 female, Montanha, São Gonçalo, 3-IV-2001, 300 m (CB); 2 males, Mata da Nazaré, 10-IX-2001, 190 m, on a Moericke trap (FA); 1 female, Levada dos Piornais, 30-I-2001, 135 m (JJ); exuviae, Boa Nova, 20-II-2002 (EF); 1 female, Penteada, 28-II-2000 (SF); 1 female, idem, 26-I-2001, $30 \mathrm{~m}$ (DAP); 1 male, 1 female, Ajuda, 8-I-2002 (OC); 1 male, Rochinha, 6-X-2000, $15 \mathrm{~m}$ (NF); 1 nymph, Levada do Bom Sucesso, 16-IV-2002, 215 m (FR). Ribeira Brava: 1 male, Levada do Norte, Boa Morte, 27-II-2003, 550 m, (FA). Machico: 1 nymph, Machico, 11-VIII-2001, 100 m (NF). Câmara de Lobos: 3 males, Câmara de Lobos, 10-IX-2001, 200 m (NF). Santa Cruz: exuviae, Santa Cruz, 18-IV-2004, 5 m (DAP); exuviae, idem, 18-IV-2004, 7 m (DAP); 1 female, Reis Magos, Caniço, 16-II-2002 (NF). Calheta: 2 males, 8 females, Paul do Mar, 15-20-IV-2004, 10-15m (EN). Ponta do Sol: 2 nymphs, Levada Nova, 10-III-2005, $490 \mathrm{~m}$ (FA and JJ). SPAIN. La Palma Island: 1 male, 3 females, Los Cancajos, 8-IV-2006, $20 \mathrm{~m}$ (DAP); 5 males, 4 females, 3 nymphs, idem. 10-IV-2006 (DAP).

Karyological Studies. In females, each ovary consists of six ovarioles, and in males, each testis consists of six follicles. Male meiotic metaphase I (MI) cells each show eight autosomal bivalents and a univalent $\mathrm{X}$ chromosome. The bivalents form a gradual size series except for the first bivalent, which is distinctly larger than the others; $\mathrm{X}$ chromosome is close in size to one of the largest half-bivalents (Fig. 10). The $\mathrm{X}$ is close in size to middle-sized chromosomes and tends to be positioned at a distance from bivalents that is characteristic of the Auchenorrhyncha as a whole (Halkka 1959). The first meiotic division is reductional, as in other Auchenorrhyncha, so two daughter metaphase II (MII) cells show respectively nine (eight autosomes plus the $\mathrm{X}$ ) and eight (only autosomes) chromosomes (Figs. 10-12). Hence, the sex determination system is $\mathrm{XO} / \mathrm{XX}$ and the diploid karyotype of the species is $2 n=16+X$ in males and $2 n=16+X X$ in females.

Ecological Studies. The first specimens collected in Madeira were sampled in 2000 and since then year after year, they have been found in an increasing number of new localities, which shows that this species is well established and spreading quickly throughout the island. It is present in the south of the island, which differs markedly in precipitation and temperature from the north and was sampled at altitudes

Table 1. Food plants of $\mathbf{S}$. orientalis in Madeira Island

\begin{tabular}{|c|c|c|c|}
\hline Plant family & Plant species & Adults & Nymphs/exuviae \\
\hline Anacardiaceae & Schinus molle $\mathrm{L}$. & + & + \\
\hline \multirow[t]{3}{*}{ Passifloraceae } & Passiflora edulis Sims f. flavicarpa Deg. & & + \\
\hline & Passiflora laurifolia $\mathrm{L}$. & & + \\
\hline & Passiflora edulis Sims & + & + \\
\hline \multirow[t]{3}{*}{ Asteraceae } & Tagetes minuta $\mathrm{L}$. & + & + \\
\hline & Osteospermum barberae (Harv.) Norl. & + & \\
\hline & Argyranthemum haematomma (Lowe) Lowe & & + \\
\hline \multirow[t]{2}{*}{ Euphorbiaceae } & Ricinus communis $\mathrm{L}$. & + & + \\
\hline & Acalypha wilkesiana Müll. Arg. & + & + \\
\hline Lauraceae & Persea americana Mill. & + & \\
\hline \multirow[t]{2}{*}{ Rutaceae } & Citrus sinensis (L.) Osbeck & + & \\
\hline & Casimiroa edulis Lave et Lex. & + & + \\
\hline Vitaceae & Vitis vinifera $\mathrm{L}$. & & + \\
\hline \multirow[t]{2}{*}{ Myrtaceae } & Psidium guajava $\mathrm{L}$. & & + \\
\hline & Eugenia uniflora $\mathrm{L}$. & & + \\
\hline \multirow[t]{2}{*}{ Malvaceae } & Lavatera cretica $\mathrm{L}$. & + & \\
\hline & Hibiscus rosa-sinensis $\mathrm{L}$. & + & \\
\hline \multirow[t]{2}{*}{ Convolvulaceae } & Ipomoea batatas (L.) Poir. & & + \\
\hline & Ipomoea $\mathrm{sp}$ & + & + \\
\hline Geraniaceae & Erodium moschatum (L.) L Hér. & + & \\
\hline Zingiberaceae & Hedychium gardneranum Sheppard ex Ker Gawl. & + & \\
\hline \multirow[t]{2}{*}{ Polygonaceae } & Rumex maderensis Lowe & + & + \\
\hline & Rumex sp & & + \\
\hline \multirow[t]{2}{*}{ Solanaceae } & Cyphomandra betacea (Cav.) Sendt. & + & + \\
\hline & Datura stramonium L. & + & \\
\hline Fabaceae & Arachis hypogea $\mathrm{L}$. & + & \\
\hline Globulariaceae & Globularia salicina Lam. & & + \\
\hline \multirow[t]{2}{*}{ Caricaceae } & Carica papaya $\mathrm{L}$ & + & \\
\hline & & 19 & 16 \\
\hline
\end{tabular}




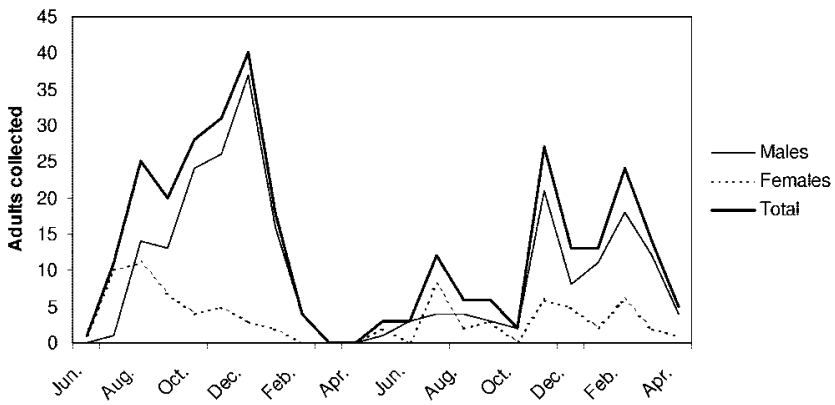

Fig. 13. Flight pattern of S. orientalis based on the monthly number of adults collected in a yellow pan trap (Moericke type), placed inside a papaya plantation between June 2000 and April 2002.

ranging from 0 to $550 \mathrm{~m}$. It was found mainly at lower altitudes in the south of the island where highly disturbed habitats exist in gardens of urban areas and in cultivated areas, as well as on native coastal vegetation. The species has been recorded from 28 plant species of 17 plant families, including ornamental plants, weeds, temperate, and tropical fruit trees, shade trees, vegetables, and vineyards (Table 1 ). These plants also include trees, bushes, and herbaceous plants. Nymphs were sampled on 16 of these plant species and of these Argyranthemum hematomma and Globularia salicina are endemic species. On most plants, both adults and nymphs were in low numbers except for A. wilkesiana, an ornamental plant common in gardens in the southern parts of the island where this species is very common. So far, there is no evidence from Madeira that some plants are unfavorable hosts. In the Canary Islands, it also was collected on A. wilkesiana, at the coast on La Palma Island. However, more sampling should be done to know the extent of this species on this archipelago.

In Madeira according to data from water pan traps, adults were present 11 mo per year except for the period between mid-March and mid-April. Adults were more common from July 2000 to January 2001, the greatest number of individuals being sampled at mid-December 2000 (Fig. 13). In 2001, the second peak was observed between July and October and the third peak between December and April 2002. There were great differences in the number of specimens sampled in each year, being greater in 2000 despite the fact that sampling was done for only half a year. The number of males was significantly greater than females $\left(\chi^{2}=50.7 \mathrm{df}=1, P=0\right)$. The trap in the orchard sampled a great number of specimens but that in the greenhouse sampled only one specimen. No nymphs were collected in Moericke traps but, from net sweeping done in several localities, nymphs were observed from July to October and from January to February.

\section{Discussion}

The specimens from Madeira and Hawaii are morphologically similar, as found previously by Webb and Viraktamath (2004). Their characteristic head shape and color pattern are sufficient to avoid any misidentification with other species of leafhoppers present in the Macaronesian archipelagos and in Europe. The shape of male aedeagus with characteristic basal and apical processes allows its separation from other species of the same genus. The diagnostic features of this genus have been outlined recently (Viraktamath and Wesley 1988, Li and Chen 2005). The presence of three apical cells in the forewings, the complex aedeagus with processes at the base of the shaft, and short male plates allows its separation from species of Kana Distant and Nirvana Kirkaldy, two other closely related genera. But, the number of species of the genus Sophonia still remains unclear, because it is very likely that several species of this genus had been wrongly assigned to other genera. Despite this, Sophonia is a large genus with $>50$ known species.

Huang (1994), after examining only the type material of Quercinirvana longicephala Ahmed and Mahmood 1970, stated that this species and Pseudonirvana rufofascia Kuoh and Kuoh 1983 were both synonyms of Nirvana orientalis Matsumura 1912, which is now in the genus Sophonia ( $\mathrm{Li}$ and Chen 1999). Despite this conclusion, all recent literature on the economic damage of this species refers to it as Sophonia rufofascia (Kuoh and Kuoh 1983). Recently, to clarify its identity, Webb and Viraktamath (2004) studied material from the United States (Hawaii and California), China, Taiwan, and Madeira (the latter supplied by D. Aguin-Pombo was collected by A. M. Franquinho Aguiar in Quebradas on water pan traps) and concluded that all belong to the same species. When Webb and Viraktamath (2004) studied the type material of Quercinirvana longicephala, they showed that this species is different from N. orientalis and established Sophonia longicephala (Ahmed \& Mahmood) as a valid name. However, they were unable to study the type material of Pseudonirvana rufofascia Kuoh and Kuoh 1983 and Nirvana orientalis Matsumura 1912. Therefore, following the first revision of Huang (1994), they tentatively retained P. rufofascia as a junior synonym of $N$. orientalis, and they provisionally identified all specimens of this leafhopper as belonging to $S$. orientalis, the current valid name.

In the family Cicadellidae, chromosome numbers of $\approx 260$ karyotyped species are reported to vary from 
$2 \mathrm{n}=8$ to $2 \mathrm{n}=28$, the karyotypes of $2 \mathrm{n}=16,18,20$, and 22 being predominant (Kirillova 1987). The data available cover as many as 18 subfamilies. Although the systematics of this very large and highly differentiated family is not sufficiently known, the majority of accepted subfamilies show rather stable karyotypes. In the subfamily Nirvaninae, to which $S$. orientalis belongs, only Pruthiana sexnotata Izzard has been karyotyped so far (Parida and Dalua 1981). This species has $2 \mathrm{n}=10+\mathrm{X} 0 / \mathrm{XX}$ in contrast to $\mathrm{S}$. orientalis showing $2 \mathrm{n}=16+\mathrm{X} 0 / \mathrm{XX}$. Although these two species display such different chromosome numbers, they have in common one large pair of autosomes and a fairly large $\mathrm{X}$-chromosome. A revision of the genera Nirvana, Sophonia and some allied genera is urgently needed to clarify their species composition and relationships. In this context the variation in chromosome number found in two studied representatives of the Nirvaninae suggests that this may be a useful character for delimitation of genera and species.

In Cicadellidae, very little is known about the structure of testes in males and ovaries in females. In about a dozen studied species, testes were shown to consist of three to 12 follicles each and ovaries of six to 12 ovarioles each, and the number six seems to dominate in both sexes (Emeljanov and Kuznetsova 1983). In the species for which the numbers are known for males and females they are more often the same in both sexes. Such is the case of S. orientalis, which displays six follicles per testis in males and six ovarioles per ovary in females.

The presence of S. orientalis in Madeira seems to be very recent. In Madeira, it was sampled for the first time in Funchal on 28 February 2000, and in La Palma (Canary Islands), we know only our specimens collected this year. However, this was only an occasional sampling; therefore, the distribution of this species on this archipelago is not known, and future work should be done. In Madeira in the last few years this leafhopper has largely increased its range, becoming widely spread all over the island. Although to date it has been found only up to $550 \mathrm{~m}$, its presence at higher altitudes is not excluded. Altitude does not seem to be a limiting factor for this species, because in the Hawaiian archipelago it was found in all types of habitats from sea level up to 1,460 m (Fukada 1996). After examining the records of live plant material imported to Madeira (DRE 1999) from 1996 to 2000, it seems possible that this leafhopper may have arrived from the United States through a shipment in 1999.

Madeira, which is situated in the Atlantic Ocean at $\approx 560 \mathrm{~km}$ from the Moroccan coast (Rabat), seems to have a very suitable climate for this species. In Hawaii, in field sampling experiments in various localities, it was observed that $S$. orientalis increases its abundance in relation to rainfall (Yang et al. 2002). The Hawaiian sites studied varied from 600 to $1,200 \mathrm{~m}$ with annual precipitation ranging from 982 to $2,322 \mathrm{~mm}$ and at least in one site at $1,200 \mathrm{~m}$ altitude temperature varied within a sampling period of a year between 13 and $18^{\circ} \mathrm{C}$. Comparing these conditions with those of Madeira at low altitudes (locality Funchal, $58 \mathrm{~m}$ ), data from the years 1941-1970 show that mean annual precipitation is $\approx 553 \mathrm{~mm}$, and temperatures in the coldest months (December-April) vary at lowest altitudes between 15.9 and $17^{\circ} \mathrm{C}$, whereas in the hottest months (July-September) they vary between 21.2 and $22.2^{\circ} \mathrm{C}$ (Quintal and Vieira 1985). In Madeira at greater altitudes, the precipitation increases, reaching at some points $>3,000 \mathrm{~mm}$ annually. These conditions are similar to those in Hawaii and may allow this species to develop several generations per year. Indeed, the presence of nymphs during at least a 5-mo period (winter and summer) and the occurrence of adults during the whole year suggest that the mild climate and the presence of hosts all year (see below) can allow this species to breed year-round with probably several annual generations. Because of a long oviposition period and a large variation in the developmental time of eggs and nymphs, overlapping generations are also likely in Hawaii (Duan and Messing 2000). The abundance on Kauai Island (Hawaii) increases from May to July when the mean rainfall is greater (Yang et al. 2002). Likewise, the greatest number of individuals registered in Madeira between September and January seems to be related to the usually high humidity levels registered during these months (Quintal and Vieira 1985).

In addition to climate, the flora of Madeira also seems to be suitable for this leafhopper. The flora comprises a wide range of taxa, including cultivated and native plants. Cultures of subtropical fruit trees such as papaya, avocado, mango, or guava are widely cultivated on this island at low altitudes. The greatest damage produced by this species to tropical crops has been registered for Psidium guajava $\mathrm{L}$., also present in Madeira, to which it can cause yield reductions of $23 \%$ in comparison with insecticide-treated trees (Jones et al. 1998). But other potential noxious effects are even of greater concern in Madeira because nymphs were observed feeding on Vitis vinifera, one of the main crops of the island, which produces the well-known Madeira Wine. In addition, this leafhopper can attack bananas, another main crop in Madeira, and of which it is a major pest in Hawaii (Howarth et al. 2001). Other ornamental plants commonly growing in gardens and cultivated for commercial purposes also may be at risk.

Widespread native plants, such as Myrica faya Aiton., presently considered to be a synonym of Morella faya, are also a suitable hosts. This endemic plant of Macaronesia is a major component of the native laurel forest in Madeira and was introduced into Hawaii where it became a weed. In Hawaii, this plant is heavily attacked by $S$. orientalis and is responsible for promoting a localized increase of the abundance of this insect, probably owing to the high nitrogen content of the leaves (Lenz and Taylor 2001, Alyokhin et al. 2004). The damage caused to M. faya consists of a reduction in diameter and stem length, lower number of nodes and reduced leaf area, and vascular bundle abnormalities (Jones et al. 2000). Although M. faya in Madeira is widely distributed, until now S. orientalis has not been recorded from it. However, because this 
native tree is a host plant, which is common in native forest areas, it may become an easy way for the leafhopper to reach many other endemic plants growing in the native laurel forest in more humid conditions (Lenz and Taylor 2001). Other highly diverse plants such as ferns, which are seriously attacked in Hawaii, also should be monitored regularly on Madeira.

The climate and flora of Madeira and the presence of many suitable hosts strongly suggest that $S$. orientalis can become a pest on this Island. In Hawaii this species has a long developmental time and may take from 3 to 4 mo to complete a single generation (Duan and Messing 2000). Therefore, it has been suggested that biological control methods may be useful (Yang et al. 2002). The identification of several species of parasitoids of the family Mymaridae both native and adventive to Hawaii (Yang et al. 2000, Johnson et al. 2001) and the fairly high rates of egg parasitization might be sufficient to keep leafhopper populations below economically damaging levels (Alyokhin et al. 2001). Likewise, in Madeira the survey of native parasitoids and the estimation of percentage of egg parasitization are necessary, because chemical and/or biological control of exotic species are not desirable owing to the likely negative impacts on the endemic flora and fauna of this island. Urgent monitoring is recommended to safeguard Europe from a new pest.

\section{Acknowledgments}

We are grateful to Gregorio Jesus for assistance in sorting material from Moericke traps and to several students and colleagues who provided leafhopper samples. We thank also C. A. Viraktamath for an initial identification of specimens from Madeira and for comparison with type material as well as for providing photocopies of useful literature. The comments of two anonymous reviewers improved the manuscript. Part of this work was financed by two Training and Mobility of Researchers grants at the Paris Museum (Colparsyst) and Madrid (Biodiberia) to D.A.-P. and by a North Atlantic Treaty Organization grant (2005) and Grant 0504 48387 of the Russian Foundation for Basic Research to V.G.K.

\section{References Cited}

Ahmed, M., and S. H. Mahmood. 1970. A new genus and two new species of Nirvaninae (Cicadellidae-Homoptera) from Pakistan. Pakistan J. Sci. Ind. Res. 12: 260-263.

Alyokhin, A. V., P. Yang, and R. H. Messing. 2001. Distribution and parasitism of Sophonia rufofascia (Homoptera: Cicadellidae) eggs in Hawaii. Ann. Entomol. Soc. Am. 94: 664-669.

Alyokhin, A. V., P. Yang, and R. H. Messing. 2004. Oviposition of the invasive two-spotted leafhopper on an endemic tree: effects of an alien weed, foliar pubescence, and habitat humidity. J. Insect Sci. 4: 1-13 (insectscience. $\operatorname{org} / 4.13)$.

Backus, E. A., M. S. Serrano, and C. M. Ranger. 2005. Mechanisms of hopperburn: an overview of insect taxonomy, behavior, and physiology. Annu. Rev. Entomol. 50: 125151.

Birdlife. 2004. BirdLife's online world database: the site for bird conservation. Version 2.0. Birdlife International, Cambridge, United Kingdom. (http:/ / www.birdlife.org).
Conger, A. D., and L. M. Fairchild. 1953. A quick-freeze method for making smear slides permanent. Stain Technol. 28: 289-293.

[DRE] Direcção Regional de Estatística da Madeira. 1999. Indicadores de actividade económica. Estrutura das explorações agrícolas 1997. Direcção Regional de Estatística, Funchal, Portugal.

Duan, J. J., and R. H. Messing. 2000. Mating, oviposition, and development of Sophonia rufofascia (Homoptera: Cicadellidae) in Hawaii. Ann. Entomol. Soc. Am. 93: 554-558.

Emeljanov, A. F., and V. G. Kuznetsova. 1983. The number of seminal follicles as a phylogenetic and taxonomic feature in the Dictyopharidae (Homoptera) and other leafhoppers. Zool. Zhurn. 62: 1583-1586.

Englund, R. A. 2004. Report for the 2003 Pacific Biological Survey, Bishop Museum Austral Islands, French Polynesia Expedition to Tubai and Rurutu. Report for the Ministère de la Promotion des Ressources Naturelles, Gouvernement de la Polynésie française, Papeete, Tahiti. Contribution 2004-001 to the Pacific Biological Survey, Bishop Museum, Honolulu, HI.

Follett, P. A., P. Anderson-Wong, M. T. Johnson, and V. P. Jones. 2003. Revegetation in dead Dicranopteris (Gleicheniaceae) fern patches associated with Hawaiian rain forests. Pac. Sci. 57: 347-357.

Fukada, M. T. 1996. Distribution, host range, and seasonal abundance of the two spotted leafhopper, Sophonia rufofascia (Kuoh and Kuoh) in Hawaii. M.S. thesis, University of Hawaii, Manoa, HI.

Grozeva, S., and S. Nokkala. 1996. Chromosomes and their meiotic behaviour in two families of the primitive infraorder Dipsocoromorpha (Heteroptera). Hereditas 125: 31-36.

Halkka, O. 1959. Chromosome studies on the Hemiptera Homoptera Auchenorrhyncha. Ann. Acad. Sci. Fenn. Ser. A. IV Biol. 43: 1-71.

Heu, R., and C.C.C. Kumashiro. 1989. Notes and exhibition. Proc. Hawaiian Entomol. Soc. 29: 16-17.

Howarth, F. G., G. M. Nishida, and N. L. Evenheius. 2001. Insects and other terrestrial arthropods, pp. 41-62. In G. W. Staples and R. H. Cowie [eds.], Hawai'i's invasive species. A guide to invasive plants and animals in the Hawaiian Islands. Mutual Publishing and Bishop Museum Press, Honolulu, HI.

Huang, K. W. 1989. Nirvanini of Taiwan (Homoptera: Cicadellidae: Nirvaninae). Bull. Soc. Entomol. NcHU 21: 6176.

Huang, K. W. 1994. Supplement of Nirvanini of Taiwan (Homoptera: Cicadellidae: Nirvaninae). Chin. J. Entomol. 14: 83-88.

Johnson, M. T., P. Yang, J. T. Huber, and V. P. Jones. 2001. Egg parasitoids of Sophonia rufofascia (Homoptera: Cicadellidae) in Hawaii Volcanoes National Park. Biol. Control 22: 9-15.

Jones, V. P., P. A. Follett, R. H. Messing, W. B. Borth, J. S. Hu, and D. E. Ullman. 1998. Effect of Sophonia rufofascia (Homoptera: Cicadellidae) on guava production in Hawaii. J. Econ. Entomol. 91: 693-698.

Jones, V. P., P. Anderson-Wong, P. A. Follett, P. Yang, D. M. Westcot, J. S. Hu, and D. E. Ullman. 2000. Feeding damage of the introduced leafhopper Sophonia rufofascia (Homoptera: Cicadellidae) to plants in forests and watersheds of the Hawaiian Islands. Environ. Entomol. 29: 171-180.

Kirillova, V. I. 1987. Chromosome numbers of the leafhoppers (Homoptera, Auchenorryncha) of the world fauna. II. Karyotypic peculiarities of the leafhoppers of the superfamily Cicadelloidea. Entomol. Rev. 66: 331-337. 
Kuoh, C. L. 1966. Homoptera: Cicadellidae. Economic insect fauna of China. Fasc. 10. Science Press. Beijing, $66-72$.

Kuoh, C., and J. Kuoh. 1983. New species of Pseudonirvana (Homoptera: Nirvanidae). Acta Entomol. Sin. 26: 316325.

Lenz, L., and J. A. Taylor. 2001. The influence of an invasive tree species (Myrica faya) on the abundance of an alien insect (Sophonia rufofascia) in Hawai'i Volcanoes National Park. Biol. Conserv. 102: 301-307.

Li, Z. Z., and X. S. Chen. 1999. Nirvaninae from China (Homoptera: Cicadellidae), pp. 29-55. Guizhou Science and Technology Publishing House, Guiyang, China.

Li,Z.Z., and X. S. Chen. 2005. A checklist and key to species of the genus Sophonia (Insecta: Auchenorrhyncha: Cicadellidae: Nirvaninae) in China with descriptions of two new species. J. Nat. Hist. 39: 71-78.

Matsumura, S. 1912. Die Acocephalinen und Bythoscopinen Japans. J. Coll. Agric. Imp. Univ. Tokyo 4: 279-325.

Moericke, V. 1955. Über die Lebensgewohnheiten der geflügelten Blattlaüse (Aphidina) unter besonderer Berücksichtigung des Verhaltens beim Landen. Z. Ang. Entomol. Hamburg 37: 29-91.

Parida, B. B., and B. K. Dalua. 1981. Preliminary studies on the chromosome constitution in 72 species of Auchenorrhyncha Homoptera from India. Chromosome Info. Ser. 31: 13-16.

Polhemus, D. 2001. The first record of Sophonia rufofascia (Homoptera: Cicadellidae) in Tahi. Proc. Hawaiian Entomol. Soc. 35: 153.

Press, J. R., and M. J. Short. 1994. Flora of Madeira. The Natural History Museum, London, United Kingdom.

Quintal, R., and M. J. Vieira. 1985. Ilha da Madeira. Esboço de geografia física. Secretaria Regional do Turismo e Cultura, Madeira, Portugal.

Sakai, A. K., F. W. Allendorf, J. S. Holt, D. M. Lodge, J. Molosfsky, K. A. With, S. Baughman, R. J. Cabin,
J. E. Cohen, N. C. Ellstrand, et al. 2001. The population biology of invasive species. Annu. Rev. Ecol. Syst. 32: 305-332.

[USFWS] United States Fish and Wildlife Service. 1995. Endangered and threatened wildlife and plants; proposed endangered status for thirteen plants from the Island of Hawaii, State of Hawaii. Fed. Reg. 60: 49377-49392.

[USFWS] United States Fish and Wildlife Service. 1996. Endangered and threatened wildlife and plants; determination of endangered status for thirteen plants from the Island of Hawaii, State of Hawaii. Fed. Reg. 61: 5313753152 .

[USFWS] United States Fish and Wildlife Service. 1997. Endangered and threatened wildlife and plants; proposed endangered status for 10 plants taxa from Maui, Nui and Hawaii. Fed. Reg. 62: 26757-26770.

[USFWS] United States Fish and Wildlife Service. 2002. Designations for critical habitat for plant species from the island of Hawaii, Hawaii. Fed. Reg. 67: 36968-37016.

Viraktamath, C. A., and C. S. Wesley. 1988. Revision of the Nirvaninae (Homoptera: Cicadellidae) of the Indian subcontinent. Great Basin Nat. Mem. 12: 182-223.

Webb, M. D., and C. A. Viraktamath. 2004. On the identity of an invasive leafhopper on Hawaii (Hemiptera, Cicadellidae, Nirvaninae). Zootaxa 692: 1-6.

Yang, P., P. A. Follett, and V. P. Jones. 2000. Oviposition behaviour and egg parasitoids of Sophonia rufofascia (Homoptera: Cicadellidae) in Hawaii Volcanoes National Park. Proc. Hawaiian Entomol. Soc. 34: 135-139.

Yang, P., D. Foote, A. V. Alyokhin, L. Lenz, and R. H. Messing. 2002. Distribution and abundance of mymarid parasitoids (Hymenoptera: Mymaridae) of Sophonia rufofascia Kuoh and Kuoh (Homoptera: Cicadellidae) in Hawaii. Biol. Control 23: 237-244.

Received 6 May 2006; accepted 10 August 2006. 